\title{
Cytopathology of spleen in eel Anguilla anguilla exposed to a chemical spill in the Rhine River
}

\author{
Eljalill Spazier, Volker Storch, Thomas Braunbeck* \\ Department of Zoology I, University of Heidelberg, Im Neuenheimer Feld 230, \\ W-6900 Heidelberg, Germany
}

\begin{abstract}
Structural alterations in the spleen of eel Anguilla anguilla L., following exposure to a chemical spill in the Rhine River in 1986, were investigated by means of light and electron microscopy. Relative abundance of reticulum and blood cells was quantified in comparison to controls. The data presented provide evidence of profound damage to the spleen and its cellular components. Histological and cytological modifications varied within a wide range from minor changes to cell death. Major cytological alterations of reticulum and blood cells included deviations in cytoplasmic density, loss of surface differentiations (cell junctions, pseudopodia), swelling of mitochondria, formation of myelin-like membrane aggregations in the cytoplasm, mitochondria, lysosomes and nuclear membrane, as weil as augmentation of lipid droplets. Severely damaged and necrotic cells were found either diffusely or focally distributed within the splenic reticulum. Melano-macrophages were strongly reduced in number and melano-macrophage centres were lacking. In contrast, considerable numbers of macrophages with intense lysosomal compartmentation, but free of pigments, were present. Spleens were further characterized by the absence of erythroblasts and plasma cells. Histological and cytological findings in the spleen of exposed eel indicate a severe impairment of the efficiency of the central splenic functions, in particular phagocytosis and cell-mediated immune response. Thus, chemical-induced pathological processes in the spleen have most likely been a contributing factor to the fatality of the chemical spill to the Rhine eel population. They are discussed in the context of earlier investigations on liver and intestine pathology of Rhine eel. Finally, cytological alterations of fish spleen are suggested as a potential biomarker for toxicant-induced damage in fish.
\end{abstract}

\section{INTRODUCTION}

Following a chemical accident at Basle in November 1986, large amounts of toxic chemicals including phosphate esters, chlorinated and heterocyclic hydrocarbons, urea derivatives, aromatic nitro and heavy metal compounds were spilled into the Rhine River causing a fish kill of hitherto unknown extent (Table 1). The selective death of certain fish species, especially eel, stimulated several investigations attempting to explain the magnitude and the underlying mechanisms of the fish kill (Kinzelbach \& Friedrich 1990). Based on toxicant concentrations measured in the Rhine immediately after the spill, no acute toxic effects were expected (Deutsche Kommission zur Reinhaltung des Rheins 1986). However, no toxicological data were available on sublethal unique effects of most of the single compounds or, in particular, on synergistic or antagonistic effects of the chemical mixture.

\footnotetext{
- Addressee for correspondence
}

One approach to elucidating the combined effects of the xenobiotics released was a thorough light and electron microscopical investigation of surviving eels. Severe injury of liver and intestine was revealed (Braunbeck et al. 1990a, Burkhardt-Holm et al. 1990). As a part of a complex syndrome of cytological alterations, tremendous invasion of macrophages and lymphocytes was observed in both hepatic and intestinal tissues indicating inflammatory processes. According to Vogelbein et al. (1987), mononuclear phagocytes ultimately forming macrophage aggregates in the liver are recruited from the peripheral circulation. Primary source for monocytes is the head kidney, and lymphocytes originate from head kidney and spleen as important lymphatic organs (Chiller et al. 1969, Pontius \& Ambrosius 1972, Ellis \& Sousa 1974, Ellis 1980).

Main functions of fish spleen comprise blood cell formation (Haider 1967a to d, Kreutzmann 1976a, b, 1977b, 1978, Lehmann \& Stürenberg 1976, Bielek 1978, 1980, Zapata 1980, D'Ippolito et al. 1985), blood cell storage and release (Miescher-Ruesch 1881, Stevens 
Table 1. Pesticides released into the Rhine River during the chemical spill at Basle in November 1986. Source: Deutsche Kommission zur Reinhaltung des Rheins (1986)

\begin{tabular}{|c|c|c|c|c|}
\hline Type of chemical & Compound & $\begin{array}{l}\text { Maximal amount } \\
\text { released }(\mathrm{kg})\end{array}$ & $\begin{array}{c}\text { Maximum } \\
\text { concentrations } \\
\text { in Rhine water } \\
\left(\mu \mathrm{I}^{-1}\right)\end{array}$ & $\begin{array}{c}\text { Maximum residue } \\
\text { concentrations } \\
\text { in Rhine fish } \\
\left(\mu g \mathrm{~kg}^{-1}\right)\end{array}$ \\
\hline \multirow[t]{9}{*}{ Phosphate esters } & Dichlorvos & 3 & $n m$ & $\mathrm{~nm}$ \\
\hline & Disulfoton & 8700 & 600 & 1900 \\
\hline & Etrimfos & 1800 & 50 & 180 \\
\hline & Fenitrothion & 288 & $<10$ & 160 \\
\hline & Formothion & 9 & $\mathrm{~nm}$ & $\mathrm{~nm}$ \\
\hline & Parathion & 690 & 200 & 34 \\
\hline & Propetamphos & 1500 & 100 & 58 \\
\hline & Quinalphos & 18 & $\mathrm{~nm}$ & $\mathrm{~nm}$ \\
\hline & Thiometon & 3600 & 500 & 390 \\
\hline \multirow[t]{3}{*}{ Chlorinated hydrocarbons } & Captafol (phthalate derivative) & 4.8 & $\mathrm{~nm}$ & $n m$ \\
\hline & Endosulfan & 60 & 0.34 & 63 \\
\hline & Tetradifon & 69 & $\mathrm{~nm}$ & $\mathrm{~nm}$ \\
\hline \multirow[t]{2}{*}{ Heterocyclic hydrocarbons } & Atrazine (triazine) & 12 & 2 & $\mathrm{~nm}$ \\
\hline & Oxadıxyl & 780 & 80 & $\min$ \\
\hline Aromatic nitro compounds & Dinitro-o-cresol & 1620 & nd & $\mathrm{nm}$ \\
\hline Urea derivatives & Metoxuron & 321 & 0.2 & $\mathrm{~nm}$ \\
\hline \multirow{3}{*}{$\begin{array}{l}\text { Heavy metal containing } \\
\text { pesticides }\end{array}$} & Ethoxyethyl mercury hydroxide & 60 & 12 & 390 \\
\hline & Zineb (thiocarbamate) & 21 & $\mathrm{~nm}$ & $n m$ \\
\hline & Zinc phosphatide & 0.39 & $\mathrm{~nm}$ & $\mathrm{~nm}$ \\
\hline
\end{tabular}

1968, Yamamoto et al. 1980), as well as destruction of effete blood cells and foreign agents by cells of the nonspecific immune response (Zwillenberg 1964, Ellis et al. 1976, Agius 1979, Fulop \& McMillan 1984, Fänge \& Nilsson 1985). Previous studies on structural and functional alterations of the haematological and immunological properties in rainbow trout showed that head kidney and spleen react very sensitively towards stress (Peters \& Schwarzer 1985, Peters et al. 1991). Under social stress, blood cells were damaged, haemopoiesis was disturbed, and the activity of phagocytes in spleen and head kidney was temporarily increased (Peters et al. 1991). Thermal stress may induce a higher frequency of macrophage aggregates (Blazer et al. 1987). Moreover, in different fish species, experimental conditions such as starvation and intoxication as well as certain infectious diseases and age were found to induce similar alterations in blood parameters and macrophage aggregates (Kreutzmann 1977a, Agius 1979, Poels et al. 1980, Agius \& Roberts 1981, Wlasow 1984, Brown \& George 1985, Wolke et al. 1985, Herraez \& Zapata 1986, Blazer et al. 1987). These results suggest altered structure and function of fish spleen as a biomarker of general environmental degradation and possibly of the toxic effects of chemicals.

So far, toxicological studies on fish spleen have been limited to light microscopic and immunologic tech- niques. There is infomation about toxic effects on general spleen histology (Poels et al. 1980, Moccia et al. 1984, Spitsbergen et al. 1988a, b), on components of the immune system and haematology (Kreutzmann 1977a, Wlasow 1984, Spitsbergen et al. 1986, Anderson et al. 1989, Laurén et al. 1989, Własow \& Dabrowska 1989), and on the coincident occurrence of melanomacrophage centres (Wolke et al. 1985, Herraez \& Zapata 1986, Kranz \& Gercken 1987). However, there are only insufficient data about the bioconcentration of toxic substances in the spleen, which is generally regarded negligible (Ribeyre \& Boudou 1984, Kleemann et al. 1986, Cossarini-Dunier et al. 1990).

Even under normal conditions, only few electron microscopical studies have been conducted on spleen cytology (Pulsford et al. 1982, Zapata 1982, Bodammer et al. 1990), phagocytosis (Fulop \& McMillan 1984), pigment genesis (Agius \& Agbede 1984), capillaries (Graf \& Schlün 1979), and blood cells (Bielek 1978, 1980, Zapata 1980, Ishizeki et al. 1984). There is a complete lack of toxicological investigations on the ultrastructure of fish spleen, although light microscopic and related studies on this organ have already proven valuable in the detection of pathological effects. Since in other fish tissues, especially the liver, electron microscopy has proved highly suitable for the demonstration of alterations induced not only by environ- 
mental factors such as temperature (Braunbeck et al 1987), starvation and different diets (Segner \& Braunbeck 1988), hibernation (Segner \& Braunbeck 1990), but also by various toxicants (Braunbeck et al. 1989, 1990a to c, 1992), toxicological investigations in fish spleen including electron microscopy deserve particular interest. Therefore, a detailed investigation of the spleen of Rhine eels exposed to the chemical spill in 1986 was initiated.

\section{MATERIALS AND METHODS}

Specimens. On 14 November 1986, 5 adult, sexually immature eels Anguilla anguilla L., which had survived the chemical spill at Basle (Rhine km 163) on 1 November 1986, were collected with nets from a groyne on the right bank of the Rhine River at Ketsch near Heidelberg (Rhine $\mathrm{km} \mathrm{406),} \mathrm{where} \mathrm{the} \mathrm{toxic} \mathrm{wave}$ reached its maximum on 3 to 5 November. Individual length ranged from 35 to $40 \mathrm{~cm}$, mean weight was $100 \mathrm{~g}$; a distinction between sexes by macroscopic features was not feasible. Control specimens (length ca $40 \mathrm{~cm}$; weight ca $100 \mathrm{~g}$ ) were obtained from upstream of Basle and from an eel hatchery in Obervolkach, Germany. Controls were adapted to laboratory conditions for $4 \mathrm{wk}$ without feeding in lots of 20 individuals in glass aquaria containing $80 \mathrm{l}$ of permanently aerated tap water (hardness $400 \mathrm{mg} \mathrm{l}^{-1} \mathrm{CaCO}_{3}$; ammonia $<0.01 \mathrm{mg} \mathrm{l}^{-1}$; oxygen saturation between 90 and $95 \%$; $21 \pm 1{ }^{\circ} \mathrm{C} ; \mathrm{pH} 7.7 \pm 0.1$. Water was constantly replaced at a flow rate of $15 \mathrm{l} \mathrm{h}^{-1}$ equivalent to a 4 -fold exchange per day. Subsequently, control fish were fed a mixture of ground trout pellets and cattle spleen at a rate of 1 to $2 \%$ wet wt $d^{-1}$ for $4 \mathrm{wk}$. No mortality occurred throughout the experimental period.

Electron microscopy. To eliminate possible effects of diurnal variation, all fixation procedures were carried out in midmorning. For electron microscopy, 5 control fish were anaesthetized in a saturated solution of benzocaine (ethyl-4-aminobenzoate) and perfused in situ via the ventricle, first with $4{ }^{\circ} \mathrm{C}$ physiological saline containing $2 \%$ polyvinylpyrrolidone (PVP, Merck, Darmstadt, Germany) and $0.5 \%$ procainhydrochloride (Merck) for 2 min to remove blood cells, and then icecold $1.5 \%$ glutardialdehyde and $1.5 \%$ formaldehyde (freshly prepared from paraformaldehyde) in $0.1 \mathrm{M}$ sodium phosphate buffer ( $\mathrm{pH}$ 7.6) containing $2.5 \%$ PVP for 10 to $15 \mathrm{~min}$. The spleen was excised immediately after perfusion and immersed as small blocks of size 2 to $3 \mathrm{~mm}$ in perfusion fixative for at least $45 \mathrm{~min}$ at $4{ }^{\circ} \mathrm{C}$.

The spleens of specimens collected from the Rhine River were fixed $1 \mathrm{~h}$ after capture by immersion of small blocks in ice-cold perfusion fixative for at least
$1 \mathrm{~h}$. In order to evaluate differences between perfusion and immersion fixation, 2 additional control specimens were fixed by immersion, but no significant dilation of blood vessels in perfused spleens could be observed.

Subsequently, tissue blocks of controls and exposed specimens were cut into thin slices of 50 to $80 \mu \mathrm{m}$ using an Oxford vibratome. Fixation was continued in $2.5 \%$ glutardialdehyde in $0.1 \mathrm{M}$ sodium cacodylate buffer $(\mathrm{pH}$ 7.6) containing $4 \%$ PVP and $0.05 \%$ calcium chloride at $4{ }^{\circ} \mathrm{C}$ for $60 \mathrm{~min}$. After rinsing in cacodylate buffer, tissue slices were post-fixed for 60 to $90 \mathrm{~min}$ at $4{ }^{\circ} \mathrm{C}$ in osmium ferrocyanide (Karnovsky 1971).

Following several passages in $0.1 \mathrm{M}$ cacodylate and $0.05 \mathrm{M}$ maleate buffer ( $\mathrm{pH} 5.2$ ), the tissue was stained en bloc with $1 \%$ uranyl acetate in maleate buffer for at least $1 \mathrm{~h}$ at $4{ }^{\circ} \mathrm{C}$. Specimens were dehydrated in a graded series of ethanol and embedded in Spurr's medium (Spurr 1969). Ultrathin sections were cut on a Reichert ultramicrotome OM U2 at a mean thickness of $100 \mathrm{~nm}$, stained with alkaline lead citrate (Reynolds 1963) for 20 to $40 \mathrm{~s}$ and examined in a Zeiss EM $9 \mathrm{~S}-2$ electron microscope.

Light microscopy. Semithin plastic sections of $0.5 \mu \mathrm{m}$ were stained with methylene blue - Azur II (Richardson et al. 1960; modified) and used for orientation in the electron microscope. Sections were mounted in Entellan and examined in a Leitz Aristoplan photomicroscope.

\section{RESULTS}

\section{Histology of control eel spleen}

The spleen of eel is a discrete elongate organ with a massive connective tissue capsule, situated in the large curvature of the stomach. Its blood supply is provided by visceral arteries, and splenic veins join the hepatic portal system (Fänge \& Nilsson 1985). Eel spleen is traversed by many arteries and veins of different sizes, among them sheathed arterial capillaries (ellipsoids). Sinusoids without a continuous endothelium are not developed in eel. Following perfusion fixation, larger blood vessels were almost free of blood (Fig. 1a), whereas a high blood cell content was characteristic of the remaining splenic reticular tissue. In eel, this reticulum is a non-septate cellular framework rich in intercellular substance, with extended spaces serving as pathways for migrating cells. Numerous large, dark melano-macrophage centres of slightly irregular shape and a diameter of up to $150 \mu \mathrm{m}$ were distributed in the tissue, mainly close to large vessels (Fig. 1a). Outside those melano-macrophage centres, neither vacuoles nor dark inclusions were apparent. 


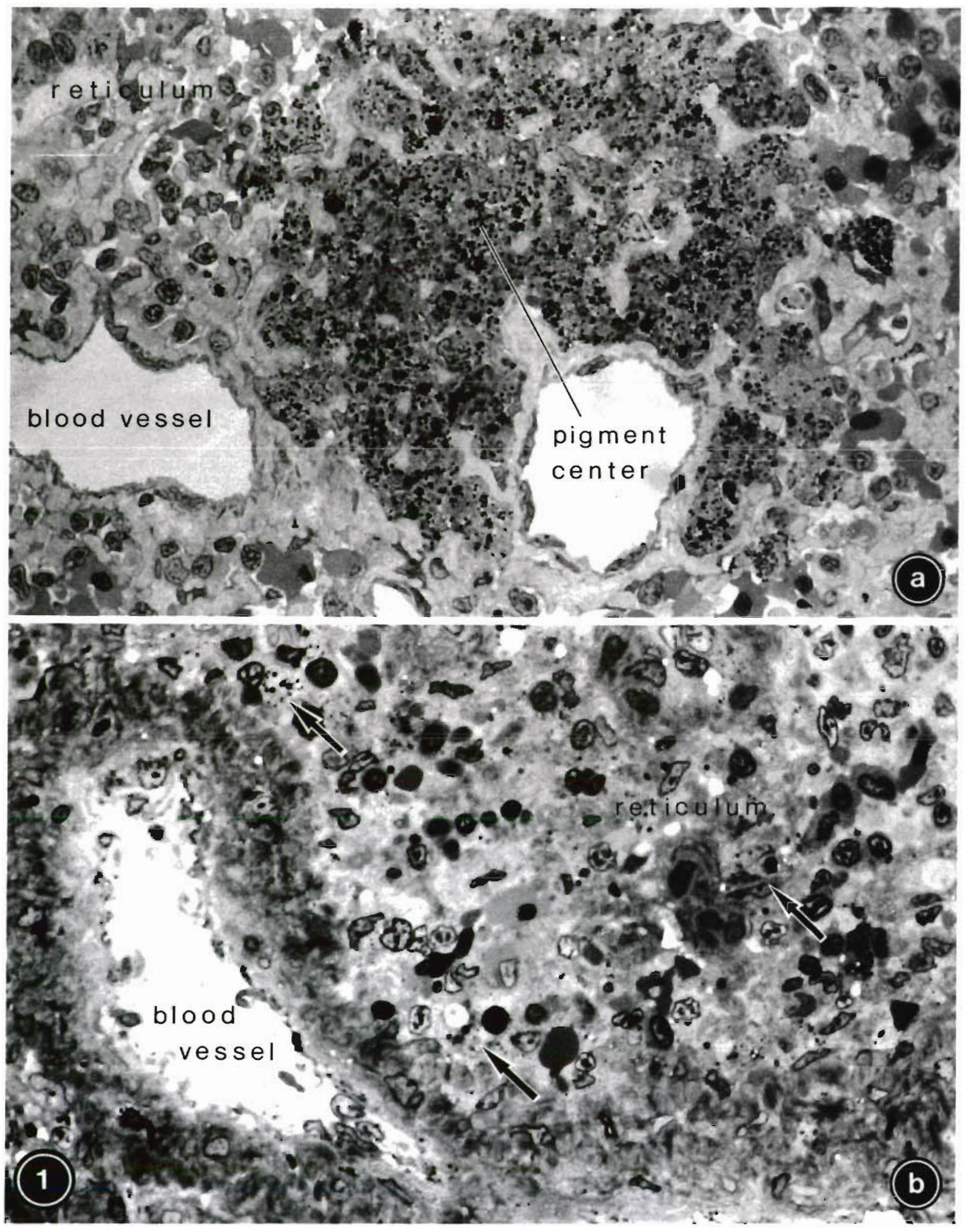

Fig. 1. Anguilla anguilla. Light micrographs of splenic tissue of (a) control eel, clearly arranged into reticulum, blood vessels (here: veins) and melano-macrophage centres (pigment center), in contrast to (b) spleen of eel exposed to the chemical spill, where melano-macrophage centres cannot be detected. Note the irregular endothelium of the blood vessel (here: artery) and several phagocytes with dark inclusions (arrows) in the reticulum. $\times 1100$ 


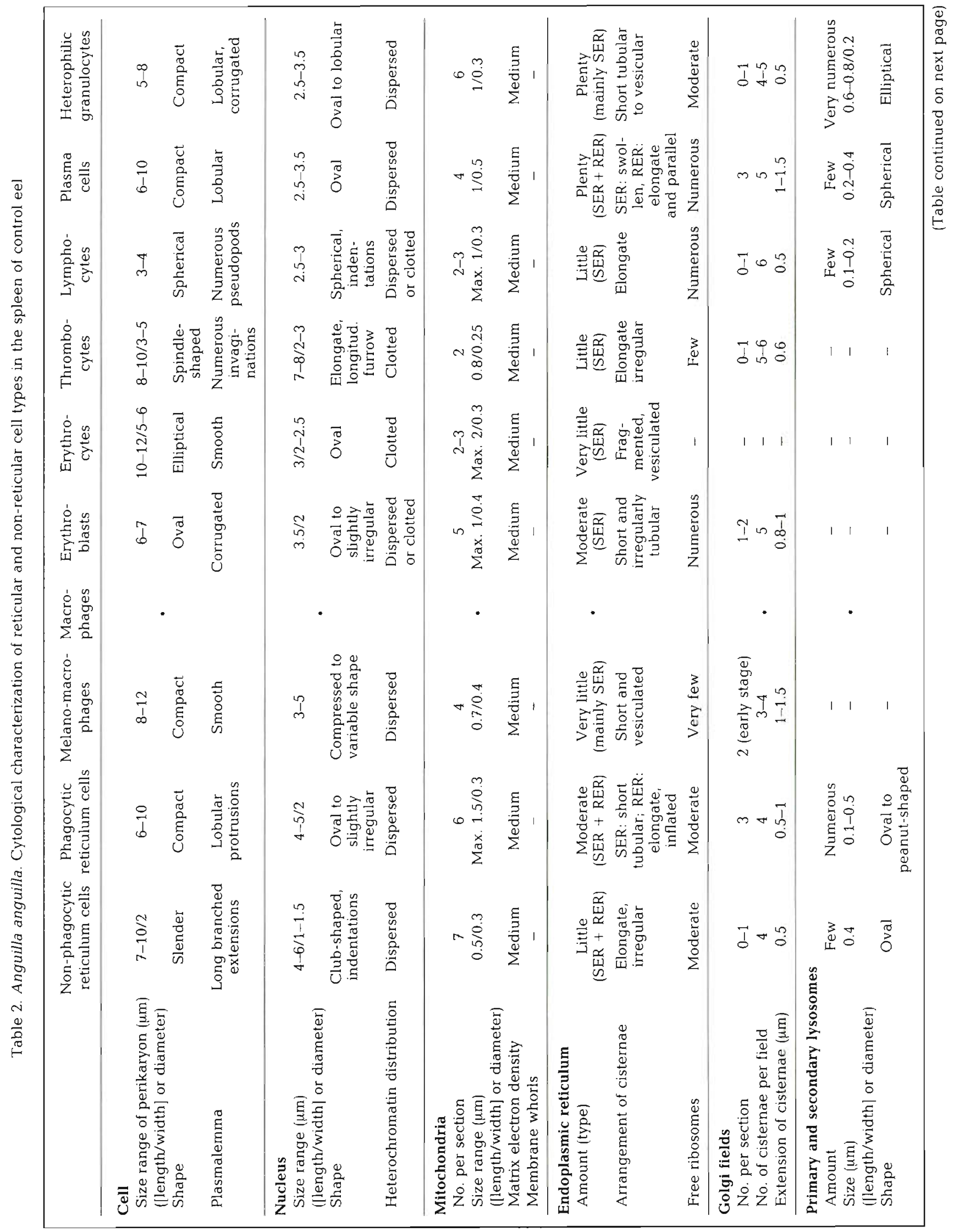




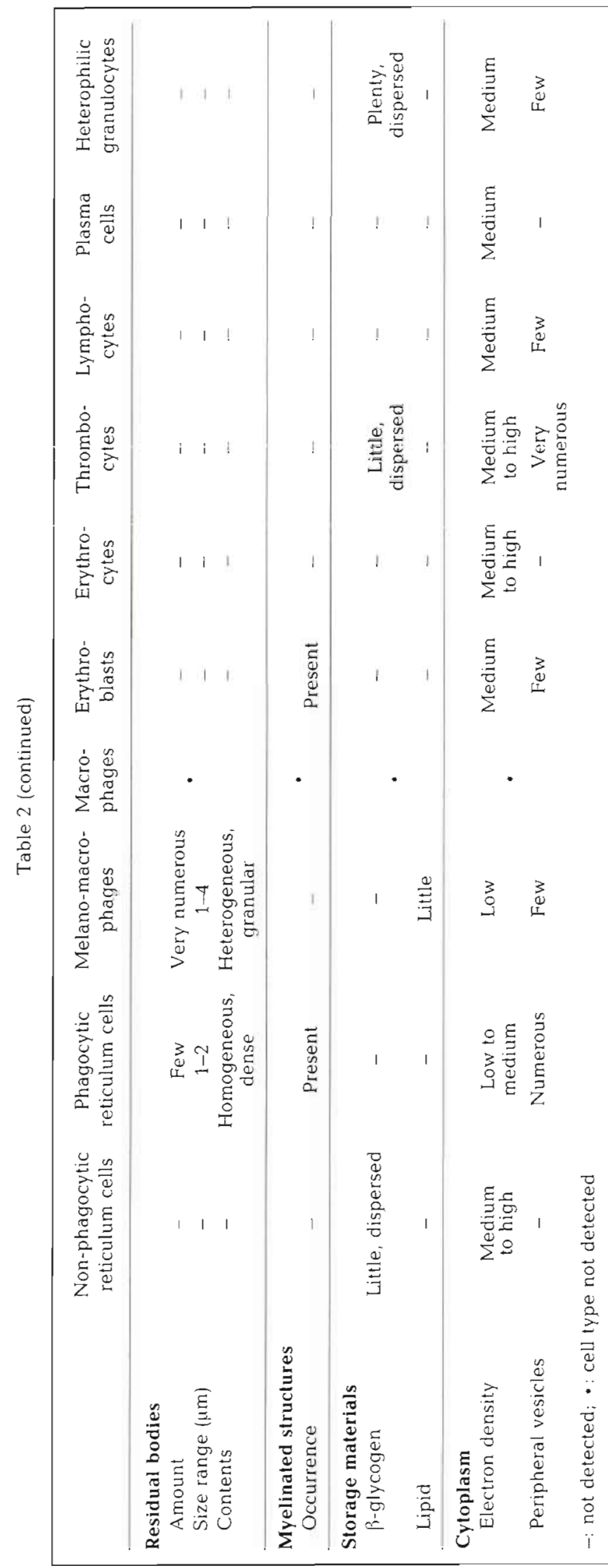

\section{Histology of Rhine eel spleen}

There were conspicuous histological alterations in the spleens of eel exposed to the chemical spill (Fig. 1b). The tissue contained considerable amounts of transparent vacuoles and dark inclusions, both of varying sizes. By means of electron microscopy, most vacuoles were identified as swollen mitochondria or, to a smaller proportion, dilated endoplasmic reticulum (ER), while the dark inclusions represented residual bodies and myelinated structures (see Figs. $3 c, d, f, g, 4 b, 5 d, e$ ). Cytoplasmic density of spleen cells showed increased variability, as compared to controls. Dark and light cells were scattered randomly. As concluded from electron microscopy, the dark cells mostly represented reticulum cells and blood cells, and a high percentage of the light cells could be identified as either dying cells or as (non-pigmented) macrophages of 8 to $12 \mu \mathrm{m}$ in diameter, a cell type not detected in controls. In contrast to controls, clearly defined, large melanomacrophage centres were not present in the spleen of Rhine eel.

\section{Ultrastructural organization of splenic reticulum}

The different cell types characterized in detail in Tables 2 (controls) and 3 (Rhine eel) could be divided into 2 main categories: (1) reticulum cells (nonphagocytic and phagocytic) constituting the permanent reticular framework, and (2) blood cells found temporarily in vessels and intercellular spaces (Fig. 2a). Whereas for non-phagocytic reticulum cells no relation to any other cell type could be documented, phagocytic cells showed transitional stages to melano-macrophages, which, therefore, might be regarded as a third (phagocytic) type of reticular cell. In controls, melanomacrophages were rarely found as single cells, but integrated in melano-macrophage centres (Fig. 2b). The cellular arrangement in controls appeared wellstructured: cellular junctions between reticulum cells were regularly established, and amorphous intercellular substance formed branching cords of 3 to $5 \mu \mathrm{m}$ thickness lined by extensions of non-phagocytic reticulum cells (Fig. 2a, cf. Fig. 3a).

In exposed eel, the splenic tissue was less clearly structured (Fig. 2C-f). Intercellular substance appeared reduced and condensed; single cords were rarely thicker than $1.5 \mu \mathrm{m}$ (Fig. 2c, d) and locally contained collagen. Cytological damage ranged from minor deviations (changes in cytoplasmic electron density, pseudopod retraction, swelling of mitochondria, formation of myelinated structures and lipid droplets) to complete necrosis of single cells or cell groups distributed heterogeneously throughout the tissue. 




Fig. 2. Anguilla anguilla. (a) Splenic retıculum and (b) melano-macrophage centre of control eel in companson to spleen of exposed eel with (c) moderately and (d) severely damaged tissue with macrophages (ma), as well as necrotic areas containıng (e) bleb-like cellular remnants and (f) dying cells Note the difference in electron-density and abundance of intercellular space (is) in controls $(a, b)$ in contrast to Rhine eel $(c, d)$. bv blood vessel; ery. erythrocyte: pc: melano-macrophage; prc: phagocytic reticulum cell; $\cdot$ thrombocyte (a), (c), (d) $\times 3000$, (b) $\times 1500$, (e) $\times 7900$, (f) $\times 8200$ 







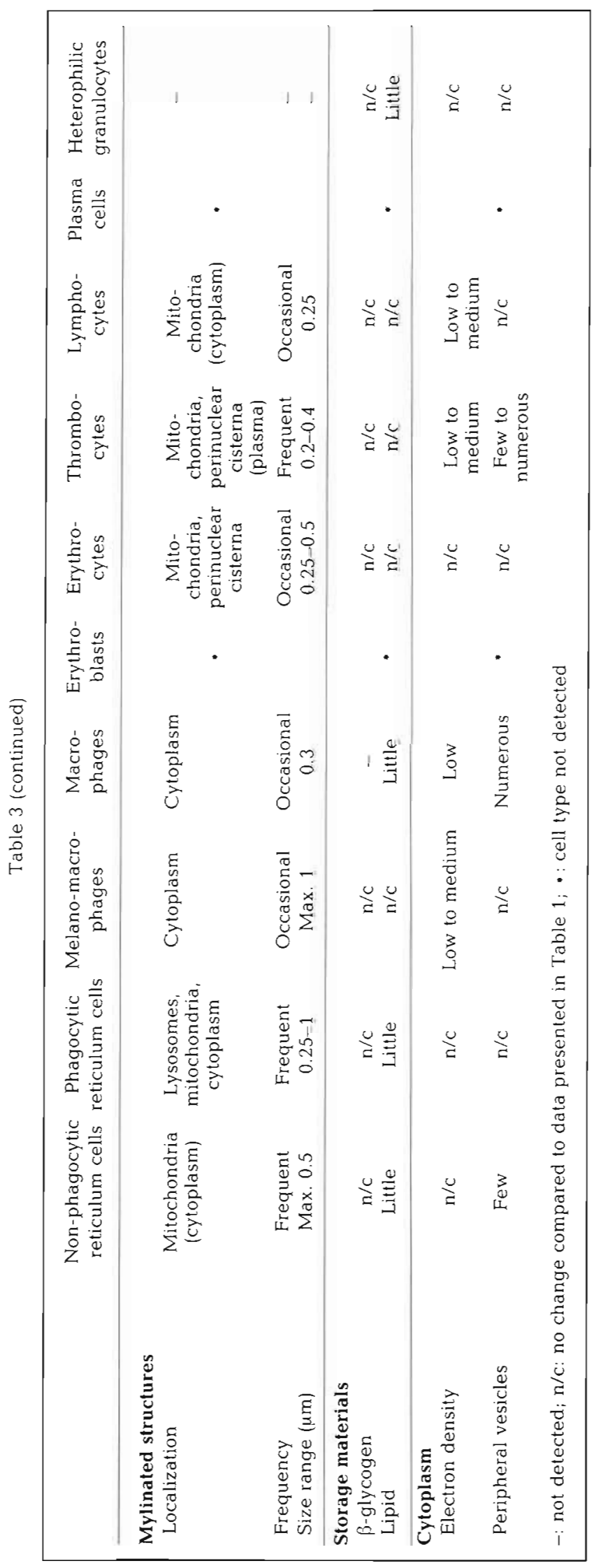

Extended areas without any change were rare. Within necrotic areas, normal reticular organization was replaced by a mixture of degenerating or necrotic blood and reticulum cells, bleb-like cell remnants containing residual bodies, and other cellular debris of unknown origin (Fig. 2e, f). Most intercellular junctions between reticulum cells were disrupted.

Semiquantitative evaluation revealed changes in the frequencies of different cell types (Table 4). Erythroblasts and plasma cells could not be detected in exposed eel. Melano-macrophage centres were not present, and the total number of melano-macrophages dispersed throughout the reticulum was reduced. In contrast, hypertrophic macrophages without pigments could only be found in exposed fish (Fig. 2d), often accumulated close to necrotic areas.

\section{Cytology of reticulum cells and macrophages}

Non-phagocytic reticulum cells in controls could be easily distinguished by their slender shape with numerous long, branching extensions establishing cellular contacts to other reticulum cells and by a clubshaped nucleus with considerable amounts of randomly dispersed heterochromatin (Fig. 3a). The cytoplasm contained few organelles in an irregular distribution, mainly mitochondria (Fig. 3b), and short bundles of microfilaments. Lysosomes were very rare.

In Rhine eel, mitochondria were increased in frequency and showed polymorphism as well as progressive swelling of up to double the control size (Fig. 3c).

Table 4. Anguilla anguilla. Semiquantitative evaluation of relative frequencies of reticular and non-reticular cell types in the spleens of control eel and eel exposed to the chemical spill in the Rhine River in November 1986

\begin{tabular}{|c|c|c|}
\hline & $\begin{array}{l}\text { Control } \\
\text { eel }\end{array}$ & $\begin{array}{c}\text { Rhine } \\
\text { eel }\end{array}$ \\
\hline Non-phagocytic reticulum cells & +++ & $++t$ \\
\hline Phagocytic reticulum cells & ++ & ++ \\
\hline \multicolumn{3}{|l|}{ Melano-macrophages } \\
\hline - reticulum & + & + \\
\hline - melano-macrophage centres & ++++ & - \\
\hline Macrophages & - & $++(+)$ \\
\hline Erythroblasts & + & - \\
\hline Erythrocytes & $++t$ & $++(+)$ \\
\hline Thrombocytes & ++ & $++\perp$ \\
\hline Lymphocytes & ++++ & +++ \\
\hline \multicolumn{3}{|l|}{ Plasma cells } \\
\hline - reticulum & + & - \\
\hline - ellipsoids & ++ & - \\
\hline Heterophilic granulocytes & + & + \\
\hline \multicolumn{3}{|c|}{$\begin{array}{l}- \text { not detected } ;+ \text { occasionally present } ;++ \text { common; } \\
+++ \text { numerous; }++++ \text { very numerous }\end{array}$} \\
\hline
\end{tabular}



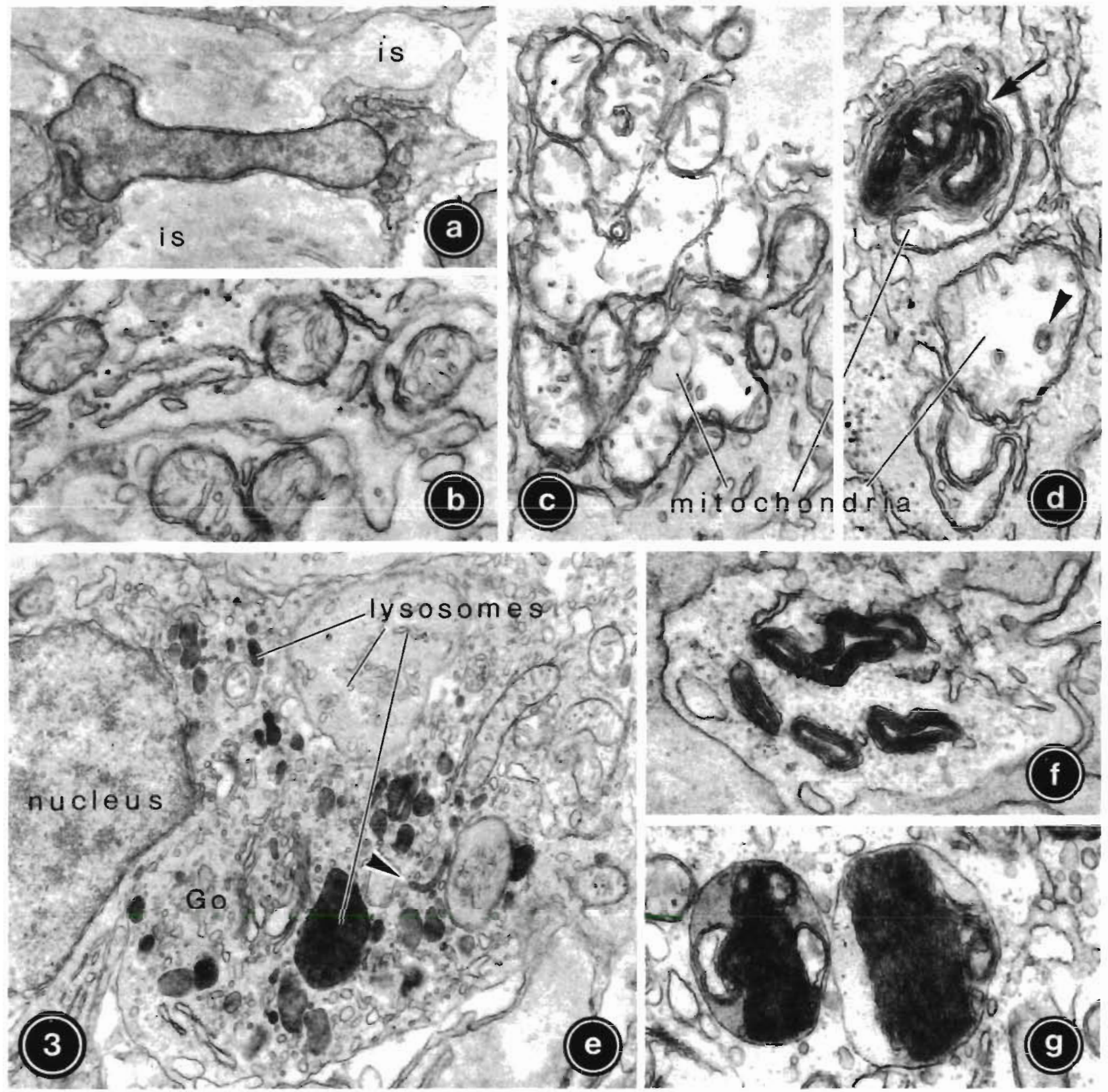

Fig. 3. Anguilla anguilla. Non-phagocytic reticulum cells in controls demonstrating (a) club-shaped nucleus, slender extensions lining spaces with intercellular substance (is) and (b) normal mitochondria in contrast to (c) mitochondrial alterations in exposed eel like swelling and polymorphism as well as (d) different stages of myelin formation (arrowhead; arrow) in the intermembranous space. (e) Phagocytic reticulum cell in controls displaying numerous lysosomes close to Golgi fields (Go) and a vermiform body (arrowhead). Major alterations in phagocytic reticulum cells of Rhine eel include (f) concentric myelinated membranes in the cytoplasm and (g) membranes arranged in parallel in lysosomes. (a) $\times 9600$; (e) $\times 18200$; (b)-(d), (f), (g) $\times 42000$

Matrix density was decreased to almost transparency. Mitochondrial membranes appeared thicker and myelin-like membrane whorls could be found in the intermembranous space (Fig. 3d). The degree of mitochondrial alterations correlated with the general damage level in the cell. Advanced injury of nonphagocytic reticulum cells was indicated by moderate swelling of ER cisternae as well as the occurrence of myelinated structures and lipid droplets in the cytoplasm.

Phagocytic reticulum cells in controls were of compact shape with lobular protrusions and showed an oval to slightly irregular nucleus with only scant, randomly dispersed heterochromatin. Numerous mitochondria, ER cisternae, Golgi fields and small-sized lysosomes of different stages were scattered through- 


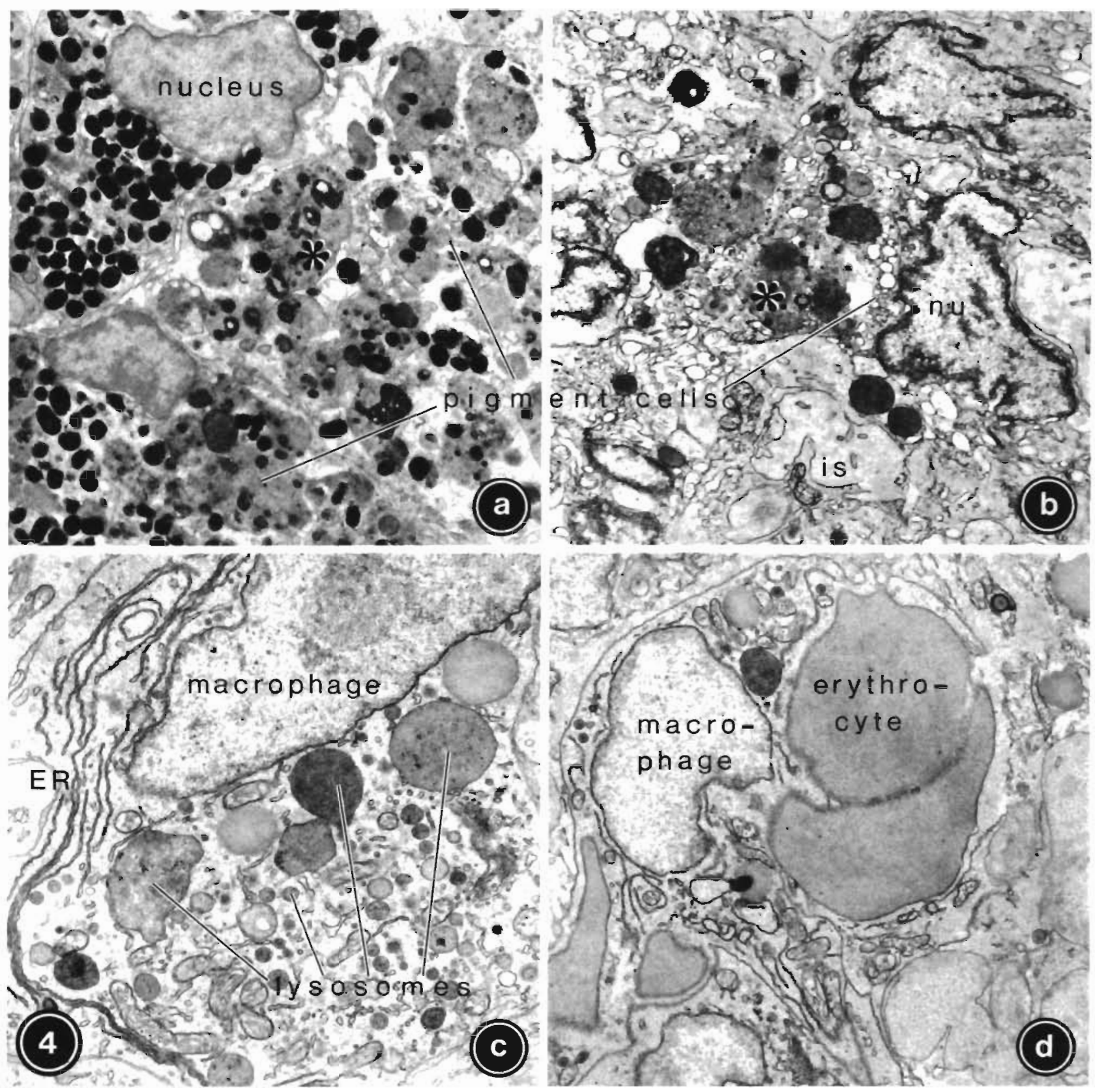

Fig. 4. Anguilla anguilla. Splenic melano-macrophages (refered to as pigment cells) heavily loaded with residual bodies (**) are (a) arranged in a melano-macrophage centre of controls, but (b) scattered in the reticulum of exposed eel, where (c, d) macrophages (labeled in nucleus) with numerous lysosomes and elongate cisternae of endoplasmic reticulum (ER) are common. In (d), note erythrocyte phagocytized by a macrophage. is: intercellular space; nu: nucleus. (a), (b) $\times 8500$; (c) $\times 14300$; (d) $\times 9900$

out the cytoplasm (Fig. 3e). Small multivesicular and myelinated structures as well as vermiform bodies in low numbers were common. Phagocytic reticulum cells with single or few pigment-containing residual bodies represented transitional stages to melano-macrophages.

The most important difference in phagocytic reticulum cells of exposed eel was the increase of myelin-like structures in organelles and cytoplasm
(Fig. 3f). Secondary lysosomes frequently contained stacks of parallel membranes (Fig. $3 \mathrm{~g}$ ). The amount of residual bodies was often augmented. Some of the mitochondria displayed signs similar to those described for non-phagocytic reticulum cells. The cisternae of rough endoplasmic reticulum (RER) were often conspicuously narrowed.

Melano-macrophages in controls were sac-shaped and characterized by a very high content of residual 


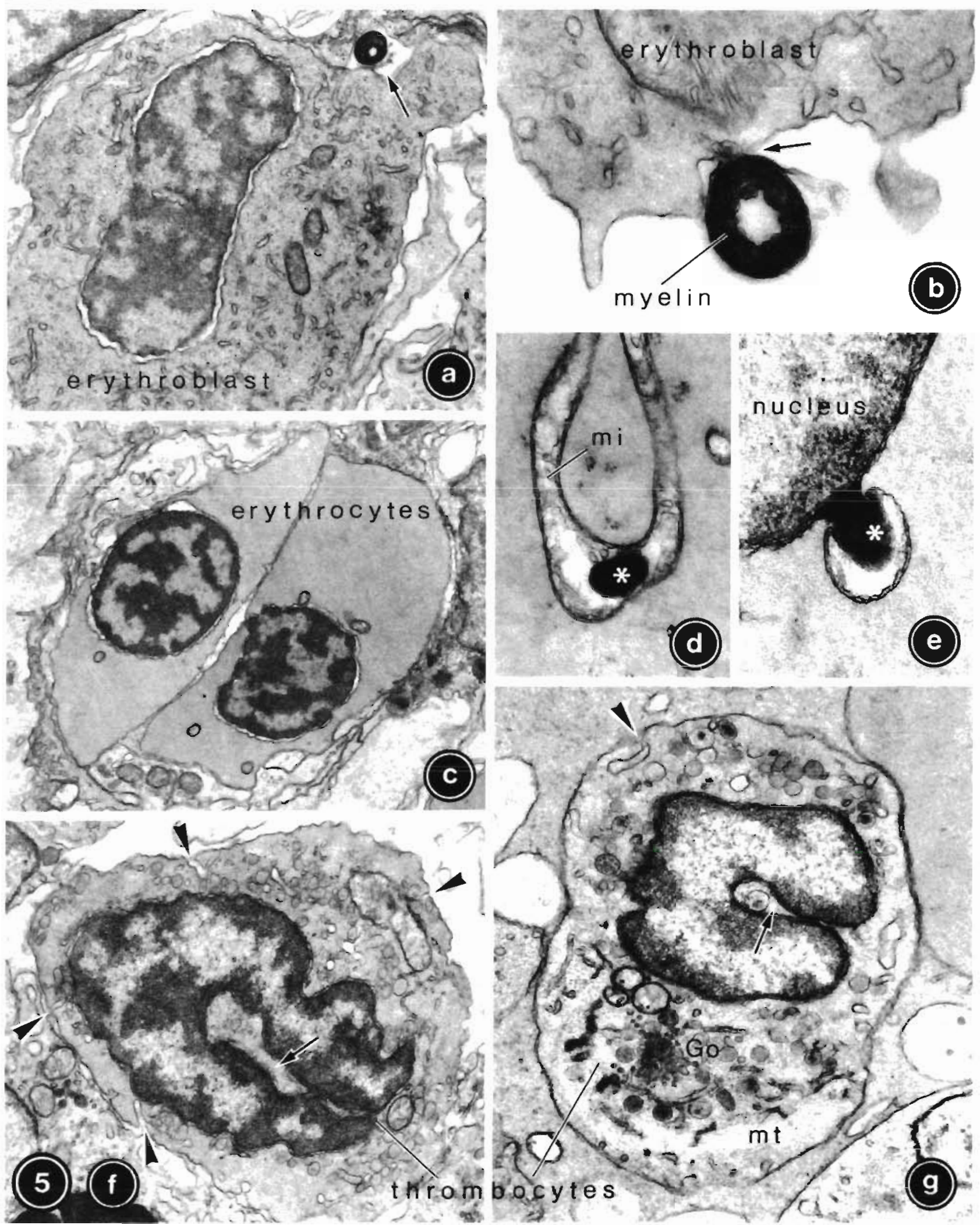

Fig. 5. Anquilla anguilla. Erythroblasts could only be observed in controls; $(a, b)$ myelinated bodies are found in close apposition to the cell surface (arrows). In exposed eel, mature erythrocytes show myelin-like structures (* $*$ in (d) mitochondria (mi) and (e) perinuclear sheath, whereas (c) controls are free of myelin formations. Thrombocytes in cross section of (f) control spleen and ( $g$ ) in a necrotic area of exposed eel spleen display differences in cytoplasmic density, vesicle population, number of invaginations (arrowheads) and depth of nuclear furrow (arrows). Go. Golgi field; mt: microtubuli belt. (a) $\times 14300 ;$ (b) $\times 47800 ;$ (c) $\times 10800$; (d), (e) $\times 42000 ;(\mathrm{f}) \times 16600 ;(\mathrm{g}) \times 18200$ 
bodies with a diameter of 1 to $4 \mu \mathrm{m}$ in contrast to the sparsity of other organelles, in particular primary lysosomes (Fig. 4a). Due to dense package of residual bodies, several nuclei were compressed. Residual bodies contained granular pigments of various size and density, embedded in a moderately electron-lucent matrix (Fig. 4a). Three types of pigments could be identified (terminology of Agius \& Agbede 1984): melanin (discrete oval granules, 0.3 to $0.5 \mu \mathrm{m}$, uniformly very dense), lipofuscin (irregular shape, up to $2.5 \mu \mathrm{m}$, varying size and electron density) and haemosiderin (finely granular, clustered, electrondense). Melanin usually predominated. Occasionally, multivesicular bodies and lipid droplets could be discerned. Some (premature?) melano-macrophages were of smaller size ( 6 to $8 \mu \mathrm{m}$ ) and contained fewer and smaller residual bodies than typical melano-macrophages, but a higher number of other organelles.

Whereas fully formed melano-macrophages were less abundant in Rhine eel, smaller melano-macrophages with a reduced number of residual bodies, but poorly developed ER and Golgi fields, were increased. Melanin content was generally reduced, whereas fine lamellar and granular materials with lipofuscin and haemosiderin portions predominated (Fig. 4b). In melano-macrophages, mitochondria did not show any swelling.

Macrophages were only observed in Rhine eel (Fig. 4c, d). They could be distinguished from similar phagocytic reticulum cells by their marked hypertrophy, being larger in size and showing more protrusions. Their oval nucleus was poor in heterochromatin and organelles were numerous in the electron-lucent cytoplasm. Compared to phagocytic reticulum cells in Rhine eel, mitochondria were twice as frequent, narrowed RER cisternae appeared increased, Golgi fields were extended, and lysosomes were more numerous and frequently contained undigested material such as erythrocytes (Fig. 4d). Moderate amounts of myelinated structures, lipid droplets, multivesicular and vermiform bodies could be observed. Some macrophages showed symptoms of cellular-injury-like rupture of cell membranes and release of cytoplasmic contents

\section{Cytology of blood cells}

Erythroblasts could in most cases be classified as late basophilic stages according to Bielek (1978). The cytoplasm of the oval cells already contained haemoglobin, but was still rich in organelles, mainly mitochondria and irregular tubular smooth endoplasmic reticulum (SER), as well as some Golgi fields, multivesicular bodies and numerous free ribosomes (Fig. 5a). Occasionally, erythroblasts exhibited ring-shaped myeli- nated bodies close to the cell surface (Fig. 5a, b) measuring 0.35 to $0.4 \mu \mathrm{m}$ in diameter and consisting of about 10 to 15 concentric membrane layers. In the spleen of eel exposed to the chemical spill, erythroblasts were not detectable.

Erythrocytes. In the elliptical erythrocytes of controls, the oval nucleus displayed wide nuclear pores and strongly condensed heterochromatin (Fig. 5c), the amount of which clearly exceeded that of erythroblasts. Except for few mitochondria and cisternae of SER, the cytoplasm was extremely poor in organelles, but rich in fine, homogeneously distributed haemoglobin. The marginal microtubuli belt of the erythrocytes was about $0.2 \mu \mathrm{m}$ thick and consisted of 8 to 10 microtubuli.

In erythrocytes of exposed eel, the nucleolus appeared more prominent than in control fish (Fig. 6b). The cytoplasm was of slightly increased density, but almost or entirely free of organelles except for few mitochondria. Some of these were swollen and showed reduced cristae in an electron-lucent to transparent matrix. Occasionally, myelin-like membrane whorls could be found in the intermembranous space of mitochondria (Fig. 5d), as well as in the locally dilated perinuclear sheath (Fig. 5e). In no case, however, were these myelin-like membrane whorls found attached to the cell surface as described for control erythroblasts.

Thrombocytes were spindle-shaped blood cells with an elongate nucleus displaying a characteristic longitudinal furrow and abundant, condensed heterochromatin (Fig. 5f). In controls, about 10 plasmalemmal invaginations per section with a diameter of about $80 \mathrm{~nm}$ could be counted. The peripheral cytoplasm contained 30 to 50 vesicles per section with a constant diameter of $0.15 \mu \mathrm{m}$ and a homogeneous matrix. Normally, the 0.5 to $1 \mu \mathrm{m}$ thick belt of microtubuli surrounding the cell along its longitudinal axis was only difficult to discern.

In exposed fish, both cell and nuclear length were reduced in thrombocytes. The nuclear furrow was frequently less prominent (Fig. $5 \mathrm{~g}$ ). Plasmalemmal invaginations were reduced in number by about $50 \%$, and their diameter was diminished to $50 \mathrm{~nm}$. Each thrombocyte displayed 10 to 50 vesicles per section, with a diameter increased by $30 \%$ to $0.2 \mu \mathrm{m}$ and a highly variable matrix. Part of the mitochondria appeared swollen with low matrix density and membranous whorls in the intermembranous space. Similarly to erythrocytes, myelinated structures were occasionally found in the perinuclear sheath. Golgi fields were diminished, and some lysosomes and multivesicular bodies were present. Due to a decrease in cytoplasmic density of severely damaged thrombocytes, the longitudinal microtubuli belt was more evident (Fig. $5 \mathrm{~g}$ ).

Lymphocytes were small, spherical blood cells displaying numerous pseudopodia and a high 

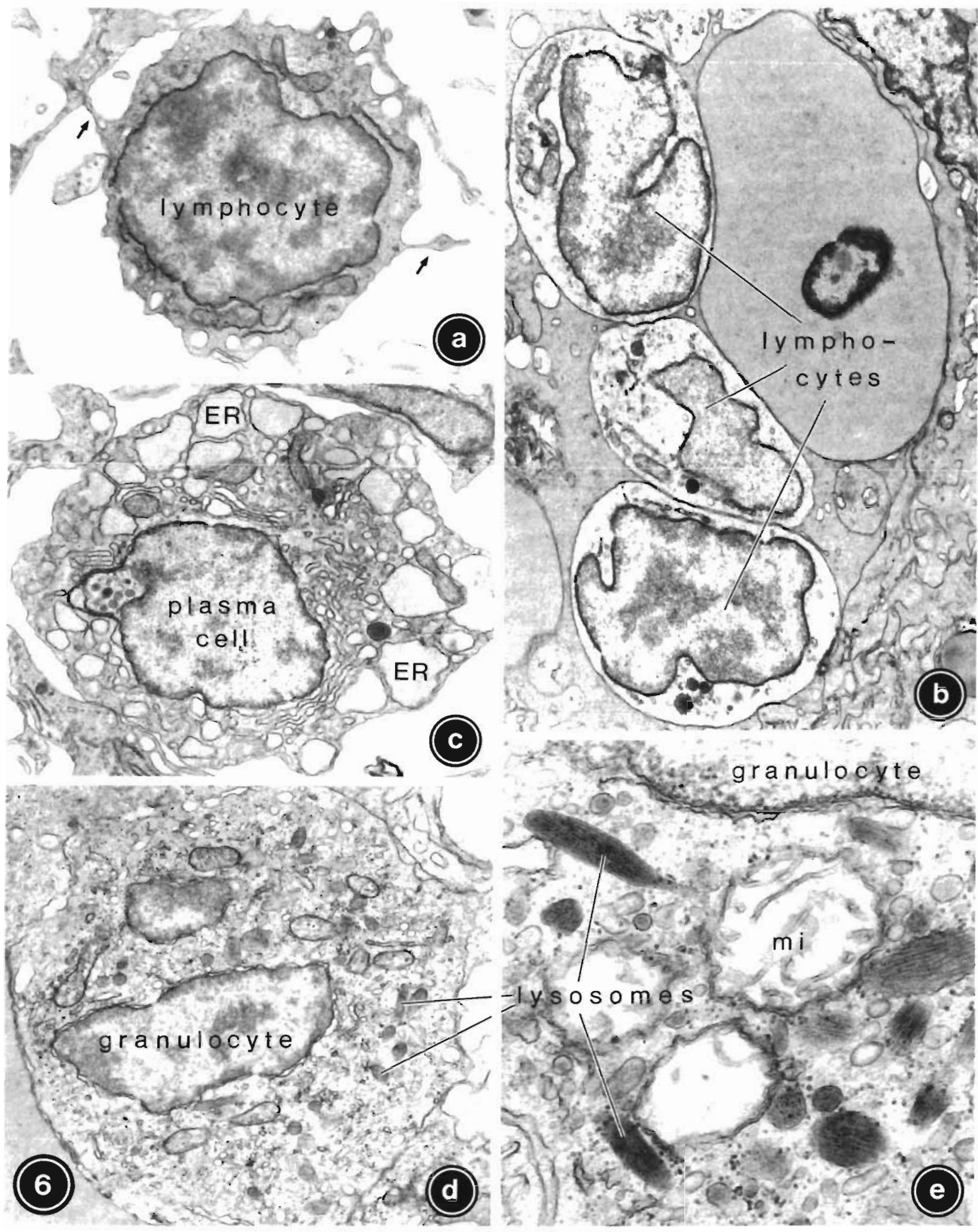

Fig 6 Anguilla anguilla. Lymphocytes (a) in control spleen and (b) in a necrotic area of Rhine eel spleen with marked differences in cell shape, electron density and pseudopodia formation (arrows in al Plasma cells characterized by distended cisternae of endoplasmic retıculum (ER) are only detectable in (c) control spleen Heterophilıc granulocytes with lobular nucleus and specific lysosomes in (d) control spleen in comparıson to (e) spleen of exposed eel, where swelling of mitochondria (mi) and a condensed lysosomal matrix are the major alterations (a) $\times 16000$, (b) $\times 11600$, (c) $\times 6000$; (d) $\times 14300$; (e) $\times 42000$ 
nuclear: cytoplasmic ratio (Fig. 6a). Except for high amounts of evenly distributed free ribosomes, the cytoplasm only contained some mitochondria, elongated cisternae of SER and few small lysosomes.

In exposed fish, cell shape and nuclei of most lymphocytes were no longer spherical. Even cells without other modifications displayed a reduction of pseudopodia, whereas the plasmalemma of severely damaged lymphocytes appeared completely smooth (Fig. 6b). In addition, the cytoplasmic density was either drastically decreased or, more rarely, increased. Further alterations included small membranous whorls within mitochondria, partial vesiculation of SER and increased density of lysosomes.

Plasma cells in control eel were more commonly found in the wall of ellipsoids than in the reticulum (Fig. 6c). Both elongate RER lamellae in parallel array and highly swollen SER cisternae could be found in the same cell. Free ribosomes were numerous. Several large Golgi fields per section were arranged in groups mainly in a perinuclear position. Golgi cisternae were inflated and intensively fenestrated. Only few lysosomes were present. In the spleens of exposed fish, plasma cells could not be detected.

Heterophilic granulocytes in controls contained an oval to lobular nucleus and numerous small organelles including mitochondria, short tubular to vesicular cisternae of SER, and primary lysosomes (Fig. 6d). These lysosomes equivalent to the specific granules in light microscopy had a characteristic elliptic shape and a crystalline matrix. Abundant $\beta$-glycogen particles were dispersed throughout the cytoplasm.

In Rhine eel, mitochondria of heterophilic granulocytes were reduced in number, some of them appeared heavily swollen, with reduced cristae in an almost transparent matrix (Fig. 6e). The electron density of the crystalline lysosomal matrix was increased, and lipid droplets of $0.5 \mu \mathrm{m}$ in diameter occurred in the cytoplasm. Heterophilic granulocytes were the only blood cell type in exposed eel that were free of myelinated structures.

\section{DISCUSSION}

The present study was designed to serve several purposes: (1) to give a comprehensive account of the histology and cytology of resident and free cells in the spleen of eel, (2) to investigate the cytopathological effects of the chemical spill into the Rhine River at Basle in November 1986 on eel spleen, (3) to assess potential functional implications of splenic cytopathology in context with earlier findings on cytological alterations in liver and intestine (Braunbeck et al. 1990a, Burkhardt-Holm et al. 1990), and, thus, (4) to evaluate the utility of splenic alterations at the ultrastructural level as a biomarker for toxicant-induced damage of fish.

To date, rainbow trout Oncorhynchus mykiss is the most-investigated species with regard to studies on fish spleen. For many other species, including eel, data are fragmentary. Except for melano-macrophage centres, which have been described by Agius (1979, 1980), Agius \& Roberts (1981), Agius \& Agbede (1984) and Roberts (1975), histology and cytology of eel spleen has not previously been investigated. A general outline of histological and cytological investigations on fish spleen is given in Tables $5 \& 6$.

Table 5. Reviews and systematical investigations on histology and cytology of fish spleen

\begin{tabular}{|c|c|c|c|}
\hline Species & Comment & Method & Reference \\
\hline (Review) & Immune response in fish & (Review) & Corbel (1975) \\
\hline (Review) & $\begin{array}{l}\text { Comparative study of lympho-myeloid tissue } \\
\text { in fish }\end{array}$ & (Review) & Fänge (1982) \\
\hline (Review) & Structure and function of fish spleen & (Review) & Fänge \& Nilsson (1985) \\
\hline $\begin{array}{l}\text { Teleosts ( } 14 \text { spp.; e.g. eel, } \\
\text { plaice, rainbow trout) }\end{array}$ & $\begin{array}{l}\text { Role of melano-macrophage centres in iron } \\
\text { storage of normal and diseased fish }\end{array}$ & $\mathrm{HC}, \mathrm{LM}$ & Agius (1979) \\
\hline $\begin{array}{l}\text { Agnatha, chondrichthyes and } \\
\text { osteichthyes ( } 72 \mathrm{spp} .)\end{array}$ & $\begin{array}{l}\text { Phylogenetic development of melano-macro- } \\
\text { phage centres }\end{array}$ & LM & Agius $(1980)$ \\
\hline $\begin{array}{l}\text { Dogfish, eel, plaice, rainbow } \\
\text { trout, tilapia }\end{array}$ & Pigment genesis in haemopoietic tissues & EM & Agius \& Agbede (1984) \\
\hline $\begin{array}{l}\text { Dogfish, eel, plaice, rainbow } \\
\text { trout, sword tail, tilapia }\end{array}$ & $\begin{array}{l}\text { Effects of starvation on melano-macrophage } \\
\text { centres }\end{array}$ & LM, MO & Agius \& Roberts (1981) \\
\hline $\begin{array}{l}\text { Carp, crucian carp, golden ide, } \\
\text { perch, rainbow trout, tench }\end{array}$ & General anatomy and histology & LM & Haider (1966) \\
\hline
\end{tabular}




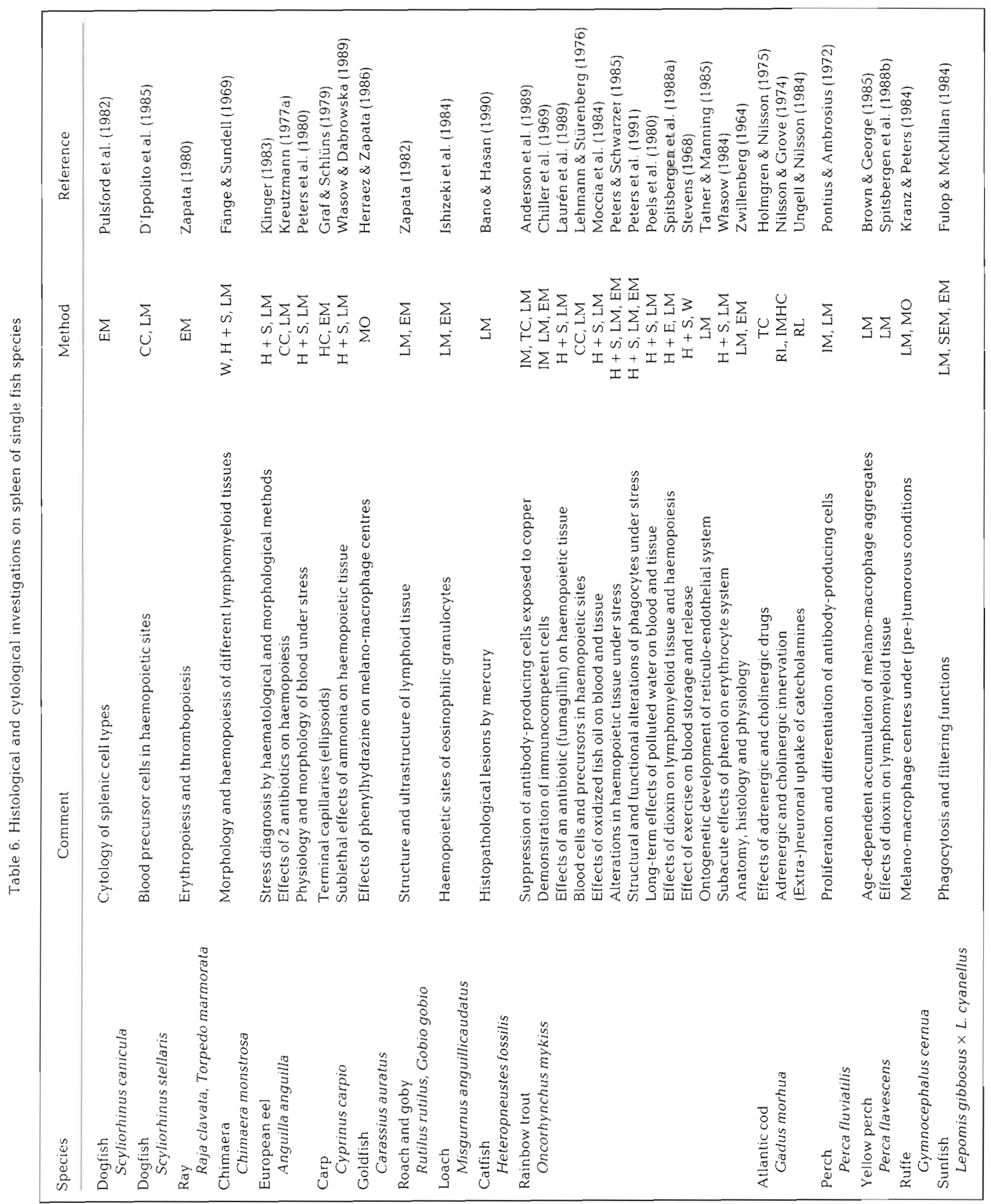




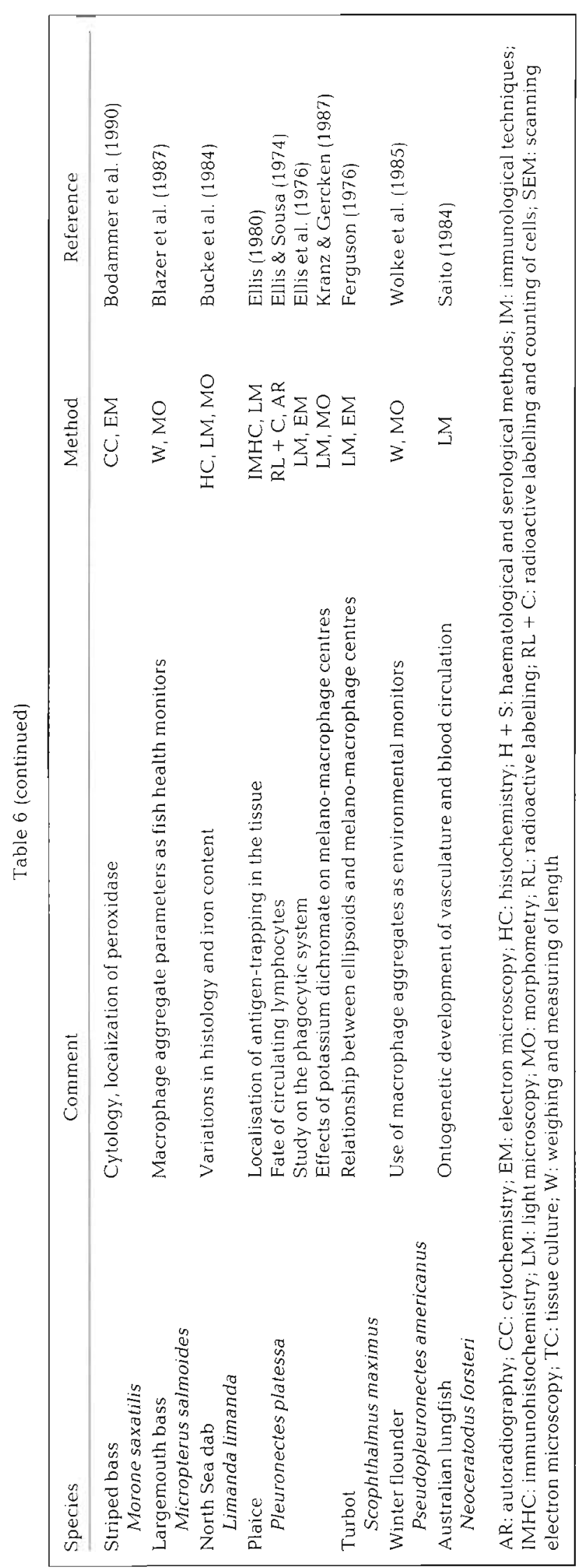

In contrast to rainbow trout (Zwillenberg 1964), the splenic reticulum of eel is characterized by a complete lack of sinusoids. However, sheathed arterial capillaries (i.e. ellipsoids) resembling those in carp spleen (Graf \& Schluns 1979) are present, and intercellular substance including a thick capsule is abundant.

Whether or not there are actually 2 separate types of reticulum cells in eel spleen remains a question of debate. According to our observations, a clear-cut distinction between phagocytic and non-phagocytic reticulum cells is possible. In contrast, intermediate stages between these 2 cell types in fish reticular tissues have been reported in ruffe spleen by Kranz (pers. comm.) and in roach and gudgeon kidney by Zapata (1979). The occasional observation of lysosomes (autophagocytosis?) in non-phagocytic reticulum cells and of microfilaments (cell skeleton?) in phagocytic reticulum cells of eel spleen, however, cannot fully confirm the existence of transitional stages between the 2 reticular cell types in this species.

Blood cell morphology, as revealed in the present study, basically coincides with the descriptions by Klinger (1983) and Kreutzmann (1976a, b, 1977b, 1978). The concentric, myelinated structures observed at the cell surface of eel erythroblasts resemble those described in rainbow trout erythroblasts (Sekhon \& Beams 1969, Bielek 1978). According to Sekhon \& Beams (1969), these lamellar bodies are extruded during erythroblast maturation. Among granulocytes, we could only document the heterophilic type, but failed to demonstrate eosinophilic and basophilic cells (Kreutzmann 1976b). Normal haemopoietic activity in eel spleen is low, which is in line with findings in most other teleost species (Pontius \& Ambrosius 1972, Fänge \& Nilsson 1985). After stimulation by blood withdrawal. granulopoiesis in eel is restricted to the head kidney, but erythropoiesis, thrombopoiesis and lymphopoiesis can also be documented in the spleen (Kreutzmann $1976 a, b, 1977 b, 1978)$.

The data presented provide clear evidence of extensive damage in the spleen of eel exposed to the chemical spill in the Rhine River in November 1986. The pathological syndrome affects all splenic cell types and ranges from slight deviations to complete destruction of cellular components and final cell death. Most striking alterations include a lack of erythroblasts, plasma cells and melano-macrophage centres, as well as the occurrence of necrotic areas in association with macrophages.

In our previous studies, a prominent immigration of macrophages into the liver parenchyma and the intestinal mucosa and submucosa was evident (Braunbeck et al. 1990a, Burkhardt-Holm et al. 1990). Cytological similarities between splenic macrophages and phagocytic reticulum cells support the hypothesis that macro- 
phages in the spleen, and possibly other organs, might arise from phagocytic reticulum cells representing a reservoir of fixed macrophages, as already suggested for fish kidney and spleen (Bertin 1958, Zapata 1979, Peters \& Schwarzer 1985). Moreover, macrophages (i.e. histiocytes) in fish tissues might additionally originate from monocytes imported via blood circulation, as documented for mammals (Sutton \& Weisser 1966) and fish (Vogelbein et al. 1987).

Likewise, the relationship of melano-macrophages to resident phagocytic reticulum cells or to mobile macrophages is subject to discussion. Since, from a cytological point of view, premature stages of melano-macrophages can be recognized as transitions between phagocytic reticulum cells and mature melano-macrophages a derivation from reticulum cells appears plausible. On the other hand, melano-macrophages are capable of active migration allowing them to (temporarily) settle in melano-macrophage centres, and, thus, share important characters with common macrophages (Ellis et al. 1976, Ferguson 1976, Kranz \& Gercken 1987).

The lack of melano-macrophage centres in the spleen of exposed Rhine eel is a striking phenomenon hitherto not reported. Due to the important function of melano-macrophage centres as repositories for metabolically inert or recycled materials (Roberts 1975) and as units competent in immune defense against microbial attack in fish ('primitive germinal centres'; Roberts 1975, Ellis et al. 1976, Ferguson 1976), their absence implicates significant negative consequences for splenic metabolism and immune defence. It is well documented that number and size of melano-macrophage centres in fish are highly variable in adaptation to actual requirements. Various adverse conditions associated with extended tissue breakdown and haemolysis cause enlargement of melano-macrophage centres in eel and other species (Agius 1979, Agius \& Roberts 1981, Wolke et al. 1985, Herraez \& Zapata 1986), whereas exposure of plaice Pleuronectes platessa to potassium dichromate results in fragmentation of splenic melano-macrophage centres along with increased numbers of melano-macrophages in splenic blood vessels (Kranz \& Gercken 1987). These authors conclude a decreased ability of melano-macrophages to accumulate, possibly due to a toxicant-induced reduction of chemotactic activity (Weeks et al. 1986). Similar processes may have been active in intoxicated Rhine eel. However, since dissipation of melanomacrophage centres should give rise to elevated numbers of scattered melano-macrophages, this hypothesis fails to explain the apparent reduction of the number of splenic melano-macrophages in total, unless emigration from the spleen is taken into account.

Even the damage of non-phagocytic reticulum cells has serious consequences for splenic functions. In necrotic areas, the reticular architecture with its rich intercellular space is broken down, and, thereby, pathways for migrating cells and blood filtration are obstructed. High amounts of tissue fragments result in an additional congestion and obstruction of the remaining intercellular space. In turn, damage of splenic phagocytes leads to a reduction of the phagocytotic capacity of the spleen.

Likewise, for some of the observations in blood cells of exposed Rhine eel, possible functional implications may be speculated. The failure to detect erythroblasts might indicate disturbance of erythropoiesis, at least in the spleen as a secondary erythropoietic organ, or reduced import of erythroblasts from the peripheral circulation. Together with an increased number of erythrocytes ingested by macrophages, this implies a significant reduction of erythrocytes in the spleen and, possibly, other organs. Oxygen depletion might result and account for part of the damage of mitochondria observed in liver (Braunbeck et al. 1990a), intestine (Burkhardt-Holm et al. 1990) and spleen.

Morphological alterations in cellular and nuclear shape of lymphocytes, lower electron density of their cytoplasm and reduction of pseudopodia in combination with the absence of fully differentiated plasma cells indicate an impairment of specific immune defense.

The augmentation of macrophages in the spleen and the induction of their phagocytic activity as indicated by an elevated number of lysosomal elements are clearly of adaptive nature. This stimulation may have been a direct effect of the chemicals, or, more likely, a consequence of the high degree of toxicant-induced necrosis resulting in debris that has to be removed. Normally, the phagocytotic capacity of the spleen in eel and other species is mainly associated with number and extent of melano-macrophage centres (Agius \& Roberts 1981, Wolke et al. 1985). In Rhine eel, however, increased numbers of macrophages may even have taken over part of the phagocytic function of disintegrated melano-macrophage centres.

In contrast to adaptive phenomena, many cytopathological reactions in the spleen of exposed fish must be interpreted as degenerative. Deviations from normal cytoplasmic density are regarded typical of dying cells (Wyllie 1981), reflecting changes in the cytoplasmic osmolality caused by disturbed plasmalemmal permeability. The early loss of surface differentiations such as pseudopodia or cell junctions, as observed in lymphocytes and non-phagocytic reticulum cells, is another common feature of cell death (Wyllie 1981). Possibly due to impeded oxygen supply mitochondria display degenerative symptoms such as swelling, destruction of cristae, formation of membrane 
whorls in the intermembranous space and reduced matrix electron density. In necrotic cells, similar changes were discussed by Wyllie (1981) in connection with altered ATP-levels.

The ER is known to be particularly sensitive to toxic impact (Wyllie 1981, Braunbeck et al. 1989, 1990a-c). A dilation or vesiculation of $E R$ cisternae as revealed in exposed eel is regarded a non-specific reaction that can be observed together with numerous functional disturbances (Wyllie 1981). Myelin formation as a prominent feature in many splenic cells may be the morphological equivalent of toxicant-induced disturbance in biomembrane synthesis, e.g., synthesis of non-functioning membranes that only consist of phospholipids (Rez 1986, Phillips et al. 1987). Such membranes fold up to form myelin-like structures and are rapidly subjected to lysosomal destruction, as frequently observed in phagocytic reticulum cells.

As indicated by the impairment of vital functions of the spleen in Rhine eel such as erythropoiesis, phagocytosis including blood clearance, concentrated deposition of non-degradable materials, as well as slight decline and damage of cells involved in the specific immune response, degenerative mechanisms apparently dominated over adaptive ones. Adaptive processes may be active in the early phases of intoxication or during exposure to very low concentrations of toxicants. Such processes have also been initiated in liver and intestinal tract of Rhine eel (Braunbeck et al. 1990a, Burkhardt-Holm et al.1990), thus demonstrating that biochemical and morphological defense mechanisms were induced prior to death of the eels. However, as with any detoxification system, sequestration of foreign compounds, proliferation of phagocytic cells as well as lysosomal compartmentation and accumulation of contaminants can only be effective as long as the capacity of the organelles is not overloaded (Hutterer et al. 1968, Ghadially 1982, Moore 1985, Braunbeck \& Völkl 1991), or the respective organelles are not irreversibly damaged by the contaminants. Apparently these defense systems were insufficient to meet the challenge in exposed Rhine eel.

From a comparison with findings in liver and gut of the same eels revealing high similarities in degree and nature of the cytopathological syndrome, it can be concluded that most of the splenic reactions towards the toxicants are not specific for spleen. The results of the alterations in all 3 organs of the Rhine eel taken together, however, give a highly complex pathological syndrome which may be specific of the accident in November 1986.

The non-specificity of splenic reaction may also be concluded from a comparison of toxicant-induced changes in Rhine eel spleen with alterations in blood, spleen and head kidney of rainbow trout under stress conditions. Peters \& Schwarzer (1985) and Peters et al. (1991) revealed severe damage to blood cells and disturbances of blood cell formation, as well as initially increased phagocytosis in combination with long-term immunosuppression. The functional alterations could be correlated to morphological deviations in rainbow trout spleen and kidney, closely resembling many of those observed in the spleen of intoxicated Rhine eel. As an interesting similarity, necrosis of macrophages is also induced in the head kidney of stressed rainbow trout (Peters et al. 1991).

Ultrastructural studies in spleen provide important information about mechanisms underlying a pathological syndrome. However, purely qualitative observations have proved not sufficient to fully appreciate the processes active during intoxication. Since major environment-induced alterations in spleen occur in size and composition of different cell populations, quantitative evaluation appears necessary, e.g. estimation of relative cell numbers or morphometric measurements of cell size. In addition, a determination of splenic phagocyte index (relative numbers of phagocytic cells per tissue area) and phagocytosis rate (as a measure for phagocytotic activity; Peters et al. 1991) might help to evaluate the extent of the toxic impact and its significance for the organism.

With regard to the chemical spill at Basle in November 1986, the data presented document that not only changes in liver and gut, but also cytopathological alterations in the spleen, may have made a significant contribution to the fatal consequences for the eel population in the Rhine. Most important, disturbances in central splenic functions may have resulted in a longterm deterioration of the immunological status of the fish giving rise to secondary infection and increased susceptibility to disease.

The present study provides a detailed inventory of possible morphological modifications resultant from exposure to a complex mixture of xenobiotic compounds in the spleen of eel. With respect to the intricacy of possible interactions between the chemicals and the sparsity of investigations on cytological effects even of single toxic compounds, it appears too speculative to attribute particular alterations to particular compounds at the present state. Laboratory studies on structural and functional effects of selected toxic chemicals involved in the chemical spill in various organs of eel have been initiated.

Acknowledgements. This study was supported by a grant from the Environmental Protection Agency of the state of Baden-Württemberg (Federal Republic of Germany) by contract no. $12 / 180.17 .24$. The authors are grateful to Dr Patricia Burkhardt-Holm for excellent cooperation and Mrs G. Adam for technical assistance. 


\section{LITERATURE CITED}

Agius, C. (1979). The role of melano-macrophage centres in iron storage in normal and diseased fish. J. Fish Dis. 2: $337-343$

Agius, C. (1980). Phylogenetic development of melano-macrophage centres in fish. J. Zool., Lond. 191: 1.1-31

Agius, C., Agbede, S. A. (1984). An electron microscopical study of the genesis of lipofuscin, melanin and hemosiderin in the haemopoietic tissues of fish. J. Fish Biol. 24: $471-488$

Agius, C., Roberts, R. (1981). Effects of starvation on the melano-macrophage centres of fish. J. Fish Biol. 19: $161-169$

Anderson, D. P., Dixon, O. W., Bodammer, J. E., Lizzio, E. F (1989). Suppression of antibody-producing cells in rainbow trout spleen sections exposed to copper in vitro. J aquat. Anim. Health 1:57-61

Bano, Y., Hasan, M. (1990). Histopathological lesions in the body organs of cat-fish (Heteropneustes fossilis) following mercury intoxication. J. environ. Sci. Health 25: 67-85

Bertin, L. (1958). Appareil circulatoire. In: Grassé, P. P. (ed.) Traité de zoologie. Tome Xill. Aynathes et poissons, zème fascicule, p. 1399. Masson et Cie., Paris

Bielek, E. (1978). Elektronenmikroskopische Untersuchungen der Blutzellen der Teleosteer: Teil I. Erythrocyten. Zool $\mathrm{Jb}$. Anat. 100: 579-591

Bielek, E. (1980). Elektronenmikroskopische Untersuchungen der Blutzellen der Teleosteer: Teil III. Granulocyten. Zool Jb. Anat. 103: 105-121

Blazer, V. S., Wolke, R. E., Brown, J., Powell, C. A. (1987) Piscine macrophage aggregate parameters as health monitors - effect of age, sex, relative weight, season and site quality in largemouth bass (Micropterus salmoides) Aquat. Toxicol. 10: 199-215

Bodammer, J. E., Anderson, D. P., Dixon, O. M. (1990). Ultrastructure of the spleen and head kidney of striped bass. J. aquat. Anim. Health 2: 182-193

Braunbeck, T., Gorgas, K., Storch, V., Volkl, A. (1987). Ultrastructure of hepatocytes in golden ide (Leuciscus idus melanotus L., Cyprinidae: Teleostei) during thermal adaption. Anat. Embryol. 175: 303-313

Braunbeck, T., Storch, V., Nagel, R. (1989). Sex-specific reaction of liver ultrastructure in zebra fish (Brachydanio rerio) after prolonged sublethal exposure to 4-nitrophenol. Aquat. Toxicol. 14: 185-202

Braunbeck, T., Burkhardt-Holm, P.. Storch, V (1990a). Liver pathology in eels (Anguilla anguilla L.) from the Rhine nver exposed to the chemical spill at Basle in November 1986. Limnologie aktuell 1: 371-392

Braunbeck, T. Görge, G., Storch, V., Nagel, R. (1990b). Hepatic steatosis in zebra fish (Brachydanio rerio) induced by long-term exposure to gamma-hexachlorocyclohexane. Ecotoxicol. Environ. Safety 19: 355-374

Braunbeck, T., Storch, V., Bresch, H. (1990c). Species-specific reaction of liver ultrastructure in zebrafish (Brachydanio rerio) and trout (Salmo gairdneri) after prolonged exposure to 4-chloroaniline. Arch. environ. Contam. Toxicol. 19: 405-418

Braunbeck, T., Völkl, A. (1991). Induction of biotransformation in the liver of eel (Anguilla anguilla L.) by sublethal exposure to dinitro-o-cresol: an ultrastructural and biochemical study. Ecotoxicol. Environ. Safety 21: 109-127

Braunbeck, T., Burkhardt-Holm, P., Görge, G., Nagel, R. Negele, R. D., Storch, V (1992). Regenbogenforelle und Zebrabärbling, zwei Modelle für verlängerte Toxizitảtstests: relative Empfindlichkeit, Art- und Organspezifität in der cytopathologischen Reaktion von Leber und Darm auf Atrazin. Verh. Ver. Wasser Boden Lufthyg. (in press)

Brown, C. L., George, C. J. (1985). Age-dependent accumulation of macrophage aggregates in the yellow perch, Perca flavescens (Mitchill). J. Fish Dis. 8: 135-138

Bucke, D., Watermann, B., Feist, S. (1984). Histological variations of hepato-splenic organs from the North Sea dab, Limanda limanda (L.). J. Fish Dis. 7. 255-268

Burkhardt-Holm, P., Braunbeck, T., Storch, V (1990). Auswirkung der beim Sandoz-Unfall im November 1986 in den Rhein gelangten Chemikalien auf die Ultrastruktur. des Darmes von Aalen. Limnologie aktuell 1 393-404

Chiller, M. J., Hodgins, H. O., Chambers, V. C., Weiser, R. S. (1969). Antibody response in rainbow trout (Salmo gairdneri). I. Immunocompetent cells in spleen and anterior kidney. J. Immun. 102: 1193-1201

Corbel, M. J. (1975). The immune response in tish: a review. J. Fish Biol. 7: 539-563

Cossarini-Dunier, M., Demael, A., Siwicki, A. K. (1990). In vivo effect of the organophosphorus insecticide trichlorphon on the immune response of carp (Cyprinus carpio): effect of contamination on antibody production in relation to resıdue level in organs. Ecotoxicol. Environ. Safety 19: 93-98

D'Ippolito, S., Grimaldi, M.C., Pica, A., Della Corte, F. (1985). The blood cells and their precursors in the haemopoietic organs of the dogfish (Scyljorhinus stellaris L.) Arch. ital. Anat. Embriol. 90: 31-46

Deutsche Kommission zur Reinhaltung des Rheins (1986) Deutscher Bericht zum Sandoz-Unfall mit Meßprogramm. Arbeitsausschuß Meßmethoden der Deutschen Kommis. sion zur Reinhaltung des Rheins. Deutsche Kommission zur Reinhaltung des Rheins, $103 \mathrm{pp}$.

Ellis, A. E. (1980). Antigen-trapping in the spleen and kidney of the plaice. J. Fish Dis. 3: 423-426

Ellis, A. E., McMunroe, A. L. S., Roberts, R. J. (1976). Defence mechanism in fish. I. A study on the phagocytic system and the fate of intraperitoneally injected particulate material in the plaice (Pleuronectes platessa). J. Fish Biol. 8: 67-78

Ellis, A. E., Sousa, M. (1974). The phylogeny of the lymphoid system. I. A study of the fate of circulating lymphocytes in plaice (Peuronectes platessa). Eur. J. Immunol. 4: 338-343

Fänge, R. (1982). A comparative study of lymphomyeloid tissue in fish. Dev. Comp. Immunol. 6 (suppl. 2): 23-33

Fänge, R, Nilsson, S. (1985). The fish spleen: structure and function. Experientia 41, 2: 152-158

Fänge, R., Sundell, G. (1969). Lymphomyeloid tissues, blood cells and plasma proteins in Chimaera Ellismonstrosa (Pisces, Holocephali\}. Acta Zool. 50: 155-168

Ferguson, H. W (1976). The relationship between ellipsoids and melano-macrophage centres in the spleen of turbot (Scophthalmus maximus). J. Comp. Pathol. 86: 377-380

Fulop, G. M. I., McMillan, D. B. (1984). Phagocytosis in the spleen of the sunfish (Lepomis spp.). J. Morph. 179: $175-195$

Ghadially, F. N. (1982). Ultrastructural pathology of the cell and matrix. Butterworths, London

Graf, R., Schlüns, J. (1979). Ultrastructural and histochemical investigation of the terminal capillaries in the spleen of the carp (Cyprinus carpio). Cell Tiss. Res. 196: 289-306

Haider, G. (1966). Beitrag zur Kenntnis der mikroskopischen Anatomie der Milz einiger Teleosteer Zool. Anz. 177 $348-376$

Haider, G. (1967a). Verglelchende Untersuchungen zur Blutmorphologie und Hämatopoese einiger Teleosteer: Teil I. Beobachtungen an Zellen der roten Reihe Zool. Anz. 179: 355-384

Haider, G. (1967b). Vergleichende Untersuchungen zur Blut- 
morphologie und Hämatopoese einiger Teleosteer: Teil II. Beobachtungen an Spindelzellen. Zool. Anz. 179: 384-409

Haider, G. (1967c). Vergleichende Untersuchungen zur Blutmorphologie und Hämatopoese einiger Teleosteer. Teil III. Beobachtungen an Lymphocyten und Plasmazellen. Zool. Anz. 180: 110-130

Haider, G. (1967d). Vergleichende Untersuchungen zur Blutmorphologie und Hämatopoese einiger Teleosteer. Teil VI. Blutbildungsstätten und Blutbildung. Zool. Anz. 181: 203-226

Herraez, M. P., Zapata, A. G. (1986). Structure and function of the melano-macrophage centres in the goldfish (Carassius auratus). Vet. Immunol. Immunopathol. 12: 117-126

Holmgren, S., Nilsson, S. (1975). Effect of some adrenergic and cholinergic drugs on isolated spleen-strips from the cod, Gadus morhua. Eur. J. Pharm 32: 163-169

Hutterer, F., Schaffner, F., Klion, F. M., Popper, H. (1968). Hypertrophic, hypoactive smooth endoplasmic reticulum: a sensitive indicator of hepatotoxicity exemplified by dieldrin. Science 161: 1017-1019

Ishizeki, K., Nawa, T., Tachibana, T., Sakakura, Y. Iida, S. (1984). Haemopoietic sites and development of eosinophil granulocytes in the loach. Misgurnus anguillicaudatus. Cell Tiss. Res. 235: 419-426

Karnowsky, M. J. (1971). Use of ferrocyanide-reduced osmium tetroxide in electron microscopy. J. Cell Biol. 52: 284

Kinzelbach, R., Friedrich, G. (1990). Biologie des Rheins. Limnologie aktuell 1. G. Fischer Verlag, Stuttgart, New York, $489 \mathrm{pp}$.

Kleeman, J. M., Olson, J. R., Chen, S. M., Peterson, R. E. (1986). Metabolism and disposition of 2,3,7,8-tetrachlorodibenzo-p-dioxin in rainbow trout. Toxicol. appl. Pharmacol. 83: 391-401

Klinger, H. (1983). Grundlagen und Anwendung hämatologischer und morphologischer Methoden zur Diagnose von Stress in der Fischhaltung unter besonderer Berücksichtigung des Aals. Ph.D. thesis, Univ. of Hamburg

Kranz, H., Gercken, J. (1987). Effects of sublethal concentrations of potassium dichromate on the occurrence of splenic melano-macrophage centres in juvenile plaice. $\mathrm{J}$. Fish Biol. 31 A: 75-80

Kranz, H., Peters, G. (1984). Melano-macrophage centres in liver and spleen of ruffe (Gymnocephalus cernua) from the Elbe estuary. Helgol. Meeresunters. 37: 415-424

Kreutzmann, H.-L. (1976a). Untersuchungen zur Morphologie des Blutes vom europäischen Aal (Anguilla anguilla): Teil I. Die Erythrocyten und ihre Entwicklungsstadien. Folia Haematol. Leipzig 103: 226-235

Kreutzmann, H.-L. (1976b). Untersuchungen zur Morphologie des Blutes vom europäischen Aal (Anguilla anguilla): Teil II. Untersuchungen zur Granulopoese. Folia Haematol. Leipzig 103: 686-700

Kreutzmann, H.-L. (1977a). The effects of chloramphenicol and oxytetracycline on haematopoiesis in the European eel (Anguilla anguilla). Aquaculture 10: 323-334

Kreutzmann, H.-L. (1977b). Untersuchungen zur Morphologie des Blutes vom europäischen Aal (Anguilla anguilla): Teil III. Beobachtungen an monozytären und lymphatischen Zellen. Folia Haematol. Leipzig 104: 538-557

Kreutzmann, H.-L. (1978). Untersuchungen zur Morphologie des Blutes vom europäischen Aal (Anguilla anguilla): Teil IV. Die Thrombozyten und ihre Entwicklungsreihe. Folia Haematol. Leipzig 105: 239-247

Laurén, D. J., Wishkovsky, A., Groff, J. M., Hedrick, R. P., Hinton, D. E. (1989). Toxicity and pharmacokinetics of the antibiotic fumagillin in yearling rainbow trout (Salmo gairdneri). Toxicol. appl. Pharmacol. 98: 444-453
Lehmann, J., Stürenberg, F. J. (1976). Hämatologische und serologische Substratuntersuchungen an der Regenbogenforelle: Teil II. Beschreibung und Darstellung der wichtigsten Zellen in der Blutbildungsstätte und im peripheren Blutgefäßsystem. Gewässer und Abwässer 55/56: 5-123

Miescher-Ruesch, F. (1881). Über das Leben des Rhein-Lachses in Süßwasser. I. Abhandlung: Die Milz des RheinLachses und ihre Veränderungen. Arch. Anat. Physiol. (Anat. Abt.): 193-218

Moccia, R. D., Hung, S. S. O., Slinger, S. J., Ferguson, H. W (1984). Effect of oxidized fish oil, vit. E and ethoxyquin on the histopathology and haematology of rainbow trout (Salmo gairdneri Rich.). J. Fish Dis. 7: 269-282

Moore, M. N (1985). Cellular responses to pollutants. Mar Pollut. Bull. 16: 134-139

Nilsson, S., Grove, D. J. (1974). Adrenergic and cholinergic innervation of the spleen of the cod, Gadus morhua. Eur. J. Pharmacol. 28: 135-143

Peters, G., Delventhal, H., Klinger, H. (1980). Physiological and morphological effects of social stress in the eel, Anguilla anguilla. Arch. Fisch. Wiss. 30: 157-180

Peters, G., Nüßgen, A., Raabe, A., Möck, A. (1991). Social stress induces structural and functional alterations of phagocytes in rainbow trout (Oncorhynchus mykiss). Fish and Shellfish Immun. 1: 17-31

Peters, G., Schwarzer, R. (1985). Changes in haemopoietic tissue of rainbow trout under influence of stress. Dis. aquat. Org. 1: 1-10

Phillips, M. J., Pucell, S. J., Patterson, J., Valencia, P. (1987). The liver: an atlas and text of ultrastructural pathology. Raven Press, New York, p. 159-238

Poels, C. L. M., van der Graag, M. A., van de Kerkhoff, J. F. J. (1980). An investigation into the long-term effects of Rhine water on rainbow trout. Water Res. 14: 1029-1035

Pontius, H., Ambrosius, H. (1972). Beiträge zur Immunbiologie poikilothermer Wirbeltiere. IX Untersuchungen zur zellulären Grundlage humoraler Immunreaktion der Knochenfische am Beispiel des Flußbarsches (Perca fluviatilis). Acta biol. med. Ger 29: 319-339

Pulsford, A., Fänge, R., Morrow, W. J. W (1982). Cell types and interactions in the spleen of the dogfish, Scyliorhinus canicula. An electron microscopic study. J. Fish Biol. 21: 649-626

Reynolds, E. S. (1963). The use of lead citrate at high $\mathrm{pH}$ as an electron-opaque stain in electron microscopy. J. Cell Biol. 17: 208-212

Rez, G. (1986). Electron microscopic approaches to environmental toxicity. Acta Biol. Hung. 37: 31-45

Ribeyre, F., Boudou, A. (1984). Bioaccumulation et repartition tissulaire du mercure - $\mathrm{HgCl}_{2}$ et $\mathrm{CH}_{3} \mathrm{HgCl}$ - chez Salmo gairdneri après contamination par voie directe. Water Air Soil Pollut. 23: 169-186

Richardson, K. C., Jarett, L., Finke, E. H. (1960). Embedding in epoxy resins for ultrathin sectioning in electron microscopy. Stain. Technol. 35: 313-325

Roberts, R. (1975). Melanin-containing cells of teleost fish and their relation to disease. In: Ribelin, W. E., Migaki, G. (eds.) The pathology of fishes. University of Wisconsin Press, Madison, p. 399-428

Saito, H. (1984). The development of the spleen in the australian lungfish (Neoceratodus forsteri Krefft), with special reference to its relationship to the 'gastro'-enteric vasculature. Am. J. Anat. 169: 337-360

Segner, H., Braunbeck, T. (1988). Hepatocellular adaptation to extreme nutritional conditions in ide, Leuciscus idus 
melanotus L. (Cyprinidae). A morphofunctional analysis. Fish Physiol. Biochem. 5: 79-97

Segner, H., Braunbeck, T (1990). Adaptive changes of liver composition and structure in golden ide during winter acclimatization. J. exp. Zool. 255: 171-185

Sekhon, S. S., Beams, H. W (1969). Fine structure of the developing trout erythrocytes and thrombocytes with special reference to the marginal band and the cytoplasmic organelles. Am. J. Anat. 125: 353-374

Spitsbergen, J. M., Kleemann, J. M., Peterson, R. E. (1988a). Morphologic lesions and acute toxicity in rainbow trout (Salmo gairdneri) treated with 2,3,7,8-tetrachlordibenzop-dioxin (TCDD). J. Toxicol. Environ. Health 23: 333-358

Spitsbergen, J. M., Kleemann, J. M., Peterson, R. E. (1988b). $2,3,7,8$-tetrachlordibenzo-p-dioxin (TCDD) toxicity in yellow perch (Perca flavescens). J. Toxicol. Environ. Health 23: 359-383

Spitsbergen, J. M., Schat, K. A., Kleemann, J. M., Peterson, R. E. (1986). Interactions of 2,3,7,8-tetrachlorodibenzo-pdioxin (TCDD) with immune responses of rainbow trout. Vet. Immunol. Immunopathol. 12: 263-268

Spurr, A. R. (1969). A low viscosity embedding medium for electron microscopy. J. Ultrastruct. Res. 26: 31-43

Stevens, E. D. (1968). The effect of exercise on the distribution of blood to various organs in rainbow trout. Comp. Biochem. Physiol. 25: 615-625

Sutton, J. S., Weisser, L. V. (1966). Transformation of monocytes in tissue culture into macrophages, epithelioid cells and multinuclear giant cells. An electron microscope study. J. Cell Biol. 28: 303-332

Tatner, M. F., Manning, M. J. (1985). The ontogenetic development of the reticulo-endothelial system in the rainbow trout. J. Fish Dis. 8: 35-41

Ungell, A. L., Nilsson, S. (1984). Neuronal and extraneuronal uptake of $\mathrm{L}-3 \mathrm{H}$-adrenaline and $\mathrm{L}-14 \mathrm{C}$-noradrenaline in the fish spleen. Acta Physiol. Scand. 122: 455-460

Responsible Subject Editor: O. Kinne, Oldendorf/Luhe, Germany
Vogelbein, W. K., Fournie, J. W., Overstreet, R. M. (1987). Development and morphology of experimentally induced hepatic melano-macrophage centers in Rivulus marmoratus. J. Fish Biol. 31, Suppl. A: 145-153

Weeks, B. A., Warinner, J. E., Mason, P. L., McGinnis, D. $S$. (1986). Influence of toxic chemicals on the chemotactic response of fish macrophages. J. Fish Biol. 28: $653-658$

Wlasow, T (1984). Erythrocyte system of rainbow trout, Salmo gairdneri Rich., affected by prolonged subacute phenol intoxication. Acta Ichthyol. Pisc. 14: 105-118

Wlasow, T., Dabrowska, H. (1989). Cellular changes in the blood and haemopoietic tissues of common carp exposed to sublethal concentration of ammonia. Ressour. Vivantes Aquat. 2: 169-174

Wolke, R. E., Murchelano, R. A., Dickstein, C. D., George, C. J. (1985). Preliminary evaluation of the use of macrophage aggregates (MA) as fish health monitors. Bull. environ. Contam. Toxicol. 35: 222-227

Wyllie, A. H. (1981). Cell death: a new classification separating apoptosis from necrosis. In: Brown, D., Lockshin, R. A. (eds.) Cell death in biology and pathology. Chapman and Hall, London. New York, p. 9-34

Yamamoto, K., Itazawa, Y., Kobayashi, H. (1980). Supply of erythrocytes into the circulating blood from the spleens of exercised fish. Comp. Biochem. Physiol. 65A: 5-11

Zapata. A. (1979). Ultrastructural study of the teleost fish kidney. Dev. Comp. Immun. 3: 55-65

Zapata, A. (1980). Splenic erythropoiesis and thrombopoiesis in elasmobranchs. An ultrastructural study. Acta zool. 61: $59-64$

Zapata, A. (1982). Lymphoid organs of teleost fish. III. Splenic lymphoid tissue of Rutilus and Gobio. Dev. comp. Immunol. 6: 87-94

Zwillenberg, H. H. L. (1964). Bau und Funktion der Forellenmilz. Academic Proefschrift, Verlag Hans Huber, Bern

Manuscript first received: November 27, 1991

Revised version accepted: June 26, 1992 